\title{
Modele wychowania dziecka we współczesnym świecie - komunikat z badań
}

Zgodnie z założeniami pedagogiki zorientowanej personalistycznie wychowanie przejawia się we wsparciu rozwoju dziecka, budowaniu jego osobowości i świata wewnętrznego, a także preferowaniu i postępowaniu według określonych wartości ogólnoludzkich. Rodzice, nauczyciele, a także cała społeczność lokalna powinni konstruować taką rzeczywistość aby dziecko coraz więcej wiedziało i lepiej rozumiało otaczający je świat, a także potrafiło poznawać i budować siebie oraz dokonywać wyborów. Podstawowym warunkiem skuteczności procesu wychowania jest dialog, czyli spotkanie dwóch równorzędnych podmiotów, które wzajemnie na siebie oddziałują i uczą się od siebie, a także wiara w człowieka, zaufanie oraz akceptowanie go takim jakim jest ${ }^{1}$.

W zmieniającym się świecie edukacja powinna być zorganizowana wokół czterech aspektów kształcenia ${ }^{2}$ uczyć się aby wiedzieć (zdobyć narzędzia rozumienia), uczyć się aby działać (oddziaływać na swoje środowisko), uczyć się, aby żyć wspólnie oraz uczyć się, aby być. W szkole, w której spotykają się uczniowie pochodzący z różnych środowisk wychowawczych i grup wyznaniowych dochodzi do wymiany zróżnicowanych poglądów, pomysłów i stylów myślenia. $\mathrm{Z}$ tego powodu kadra pedagogiczna powinna umożliwiać uczniom zaprezentowanie własnej osoby $\mathrm{w}$ atmosferze szacunku i zrozumienia. Współpraca, współdziałanie, akceptacja i zdrowa rywalizacja są motywacją do kreatywnych zachowań dzieci i młodzieży. W toku nauczania zintegrowanego nauczyciele wpływają na rozwój psychospołeczny, fizyczny i umysłowy dziecka, w tym również na rozwój jego aktywności twórczej. Postawy i działania nauczycieli w tym wczesnym okresie kształcenia są także znaczące $\mathrm{w}$ późniejszych fazach życia. Zapoczątkowanie w procesie kształcenia elementarnego kształtowania pewnych zachowań, nawyków, kształtowania umiejętności w za-

${ }^{1}$ J. Izdebska, Wychowanie - rozumiane jako pomoc w rozwoju dzieci i młodzieży, [w:] Wychowanie - ale jakie?, pod red. E. J. Kryńska, ks. A. Skreczko, Białystok 2007.

${ }^{2}$ Edukacja. Jest w niej ukryty skarb. Raport dla UNESCO Międzynarodowej Komisji do spraw Edukacji dla XXI wieku pod przewodnictwem J. Delorsa, Stowarzyszenie Oświatowców Polskich, Warszawa 1998. 
kresie twórczego myślenia i rozwiązywania problemów, współpracy i współdziałania $\mathrm{w}$ grupie, stosowania metod heurystycznych w procesie uczenia się wpływa na bardziej efektywne funkcjonowanie człowieka w społeczeństwie.

\section{Wymagania społeczne wobec nauczycieli}

Nauczyciele to grupa zawodowa, która spośród innych wyróżniają cechy osobowości ${ }^{3}$ oraz realizowane funkcje ${ }^{4}$. Do pierwszej grupy obok powszechnie wymaganych przez pracodawców cech zaliczyć należy te, które profesję nauczycielską pozwalają analizować w kategoriach powołania, misji i pasji rozumianych jako ponadprzeciętne zamiłowanie. Wielość i różnorodność pełnionych przez nauczycieli funkcji to kolejny czynnik różnicujący tę grupę zawodową od innych. Zadaniem nauczycieli jest nie tylko opiekowanie się dziećmi i młodzieżą oraz organizowanie procesu dydaktyczno-wychowawczego. Realizują też funkcje: informacyjna, motywacyjna, kontrolno-korekcyjną, środowiskową oraz badawczą. Kolejne wymagania związane z przekazywaniem jak najbardziej aktualnej wiedzy, pojęć i faktów pojawiły się wraz z rozwojem nowoczesnych technologii informacyjnych i wynalazków naukowych ${ }^{5}$. Aby móc zrealizować te wszystkie postulaty i wymagania każdy nauczyciel kształtuje odmienny styl pracy z uczniami. Jest on wypadkową wielu czynników, począwszy od indywidualnych cech osobowościowych nauczyciela, jego doświadczeń w pracy pedagogicznej, preferowanych koncepcji pedagogicznych jak i charakteru oraz potrzeb uczniów. Profesjonalizm nauczyciela przejawia się poprzez świadomy i refleksyjny wybór stylu nauczania, który umożliwi realizację najważniejszych celów pracy dydaktycznej i wychowawczej ${ }^{6}$. Przejawiane przez nauczyciela postawy i zachowania wpływają na rozwój dziecka, w tym również na podejmowanie przez nie aktywności twórczej. W nowoczesnym społeczeństwie istotne jest przygotowanie uczniów do twórczej działalności. Obejmuje ona zachowania, które są odpowiedzią na rosnącą złożoność i dynamikę współczesnego świata oraz zdolność do uczenia się nowych wzorów zachowania $w$ odpowiedzi na określone wymogi środowiska oraz modyfikacje warunków $\dot{z} y$ cia $^{7}$.

${ }^{3}$ S. M. Kwiatkowski, Oczekiwania społeczne wobec nauczycieli - w kierunku szlachetnej utopii, [w:] Nauczyciel w świecie wspótczesnym, pod red. B. Muchacka, M. Szymański, Kraków 2008.

${ }^{4}$ J. Poplucz, Funkcje nauczyciela $w$ procesie dydaktyczno-wychowawczym, „Chowanna” 1998, nr 2.

${ }^{5}$ M. K. Grzegorzewska, Wptyw zmian wynikajacych z reformy oświaty na poziom stresu $w$ grupie zawodowej nauczycieli, [w:] Nauczyciel w świecie wspótczesnym, pod red. B. Muchacka, M. Szymański, Kraków 2008.

${ }^{6}$ G. D. Fenstermacher, J. F. Soltis, Style nauczania, Warszawa 2000.

${ }^{7}$ R. Schulz, Twórczość. Spoteczne aspekty zjawiska, Warszawa 1990. 
W rozwoju zawodowym nauczycieli uobecnia się mechanizm kształtowania człowieka zgodny ze wymaganiami i myśleniem społecznym. Przedstawiciele tej profesji ze względu na stały kontakt z rodzicami swoich uczniów posiadają dobre rozeznanie $w$ zakresie oczekiwań kierowanych pod ich adresem. Należą do nich przede wszystkim skuteczne przekazywanie wiedzy oraz cechy osobowościowe sprzyjające wychowaniu i nauczaniu. Nauczyciel powinien także przekazywać wartości, wychowywać młodzież, poświęcać się dla swojej pracy oraz być autorytetem dla wychowanków ${ }^{8}$. Z innych badań wynika, że od współczesnego nauczyciela oczekuje się, że w miejsce przekazywania i egzekwowania wiedzy powinien stać się życzliwym doradcą i partnerem ucznia $\mathrm{w}$ procesie $\mathrm{w}$ miarę samodzielnego zdobywania informacji i kształtowania umiejętności ${ }^{9}$. Społeczeństwo stawia przed nauczycielami zadania przeznaczone dla specjalnie, starannie wybranej grupy osób, jednak w rzeczywistości realizuje je grupa osób do której istnieje powszechny dostęp a cechy osobowości nie są identyfikowane. Zjawisko to, w literaturze określane jest jako społeczne traktowanie grupy zawodowej o charakterze inkluzywnym jako grupy ekskluzywnej ${ }^{10}$. Wielość stawianych wymagań wynika z przenoszenia odpowiedzialności za realizowanie zadań edukacyjnych z rodziny i całego społeczeństwa na wybraną grupę zawodową. Wynikiem tego jest nakładanie na nauczycieli coraz większej odpowiedzialności i jednocześnie obwinianie ich za braki i niedociągnięcia w systemie edukacji.

\section{Modele wychowania dziecka we współczesnym świecie według Hansa Sanera}

Wzajemne relacje między nauczycielem/wychowawcą a dzieckiem powstają na podstawie intersubiektywności. W pedagogice postaci jest ona rozumiana jako postrzeganie, pojmowanie oraz traktowanie dziecka jako integralnie wewnętrznego i pełnowartościowego człowieka. W tak pojmowanym wychowaniu dziecko ma możliwość poznawania siebie, realizowania własnych celów i brania odpowiedzialności za własne postępowanie ${ }^{11}$. Podstawą takiego podejścia nauczycieli wobec powierzonych ich opiece dzieciom jest sięgnięcie do własnego dzieciństwa. Ma to na celu odkrycie i uświadomienie różnego rodzaju zachowań, niespełnionych marzeń, zablokowanych uczuć, które wpływają na postawę jaką przyjmują w procesie wychowania. Ujawnienie tłumionej aktyw-

\footnotetext{
${ }^{8}$ H. Kwiatkowska, Tożsamość nauczycieli. Między anomiq a autonomiq, Gdańsk 2005.

${ }^{9}$ M. J. Szymański, W poszukiwaniu drogi. Szanse i problemy edukacji w Polsce, Kraków 2004.

${ }^{10}$ S. M. Kwiatkowski, Oczekiwania społeczne..., s. 28.

${ }^{11}$ B. Śliwerski, Pedagogika dziecka. Studium pajdocentryzmu, Gdańsk 2007.
} 
ności i twórczości umożliwi przyjęcie postawy wspierającej wewnętrzny rozwój i samorealizację wychowanków ${ }^{12}$.

Podczas wzajemnych interakcji dorośli mają określone wyobrażenia o dzieciach, kierują $\mathrm{w}$ ich stronę różne oczekiwania, aktywnie na nie oddziałują. Zdaniem szwajcarskiego pedagoga Hansa Sanera pomiędzy wychowawcami a dziećmi mogą powstać odmienne typy relacji opartych na podporządkowaniu, równoważności lub względnej niezależności. Na tej podstawie wyróżnia on trzy modele wychowania dziecka we współczesnym świecie ${ }^{13}$ : model wychowania bazujący na tym, czym dziecko ,jeszcze nie jest”, model równości w relacji dziecka z dorosłym oraz model samowychowania dziecka.

\section{A. Model wychowania bazujący na tym, czym dziecko ,jeszcze nie jest"}

Model wychowania bazujący na tym, czym dziecko ,jeszcze nie jest” opiera się na założeniach marginalizacji akcentującej przewagę dorosłych nad dziećmi. Dorośli traktowani są jako naprawdę uspołecznieni, dojrzali psychicznie, duchowo i fizycznie wychowawcy natomiast dzieci są ich wychowankami. To oni wskazują ramy kulturowe pierwszego środowiska wychowawczego dziecka, czyli rodziny oraz ustalają prawa, porządek oraz czas pracy w szkole. Kierują procesem socjalizacji, ograniczają życie dziecka przez negatywną selekcję, formują i zmieniają dziecko, bo mają prawo „zrobić z niego człowieka”.

Podstawowym wyznacznikiem tożsamości dziecka jest w tym modelu „brak”. Dziecko nie jest człowiekiem, nie jest mądre, kulturalne, samodzielne, a w związku z tym nie może decydować o swoich własnych i społecznych sprawach. Mimo, że dziecko posiada prawa, to nie może z nich w pełni korzystać. Nie ponosi odpowiedzialności za swoje niepowodzenia lub sukcesy ponieważ dorośli nie przypisują mu sprawczości jego działań. Kultura dziecięca tworzona jest tylko przez dorosłych, a dziecko przez podejmowaną aktywność nie wzbogaca jej, a tylko z niej korzysta. Wychowanie i rozwój oparte są o negatywną selekcję, czyli bardziej istotne jest to, czego wychowanek nie potrafi niż to co umie.

W tym modelu dziecko traktowane jest jako obiekt wychowawczy. W wychowaniu istotną rolę odgrywa autorytet wynikający z dominacji nad dzieckiem, przymus, polecenia, posłuszeństwo oraz nierówność wobec prawa. Odbywa się ono dzięki ćwiczeniom, w wyniku których dziecko nabywa umiejętności dorosłych oraz abstynencję, czyli przeświadczenie u podstaw którego leży ków 2001.

${ }^{12}$ H. Dauber, Obszary uczenia się przyszłości. Perspektywy pedagogiki humanistycznej, Kra-

${ }^{13}$ B. Śliwerski, Pedagogika dziecka..., Gdańsk 2007. 
założenie, że dziecko nie może opanować umiejętności dorosłych ponieważ są one zastrzeżone tylko dla nich. Opisywany model ma wiele cech kultury postfiguratywnej Margaret Mead $^{14}$ - dzieci uczą się głównie od rodziców. Zmiany zachodzą powoli i są trudne do zauważenia. Wśród pokolenia starszego dominuje przekonanie, ze sposób życia nie zmienia się, a w związku z tym młodsi powinni realizować ich oczekiwania.

\section{B. Model równości, izonomii w relacji dziecka z dorosłym, ,bycia takim samym człowiekiem jak dorosły”}

Model równości w przeciwieństwie do modelu pierwszego koncentruje się na tym co łączy dorosłych i dzieci. Wspólną cechą jest sam fakt bycia człowiekiem oraz równość bez względu na różnice rozwojowe. Obie strony wzajemnie się wychowują i samowychowują, bo prawa człowieka powinny wszystkim gwarantować szanse na swobodny rozwój. Wychowanie to partnerska relacja dwóch stron oparta na rozpoznawaniu mocnych stron jednostki, na tolerancji i wspólnych zasadach. Wynika to z przekonania, że dzieci obdarzane miłością i szacunkiem są bardziej podatne na uniwersalny wymiar humanizmu, czyli na miłość bliźniego. Autorytet nie wynika z dominacji nad kimś, wymuszającej szacunek, a rozumiany jest jako obustronna relacja w której dwie strony moga być autorytetem: dorosły $\mathrm{z}$ racji wieku, umiejętności, a dziecko z powodu większej umiejętności uczenia się, elastyczności i spontaniczności.

W takich relacjach nie ma potrzeby wydawania poleceń, ani przekonywania. Solidarnie dochodzi się do wspólnych ustaleń, wspiera się rozwój sił i dyspozycji zamiast negatywnej selekcji oraz tworzy się otwartą wspólnotę. Dziecko nie jest uzależnione od dorosłych i nie pozostaje poza społecznością. Jest uczestnikiem wspólnoty, wnosi do niej coś na miarę swoich możliwości. Mając taki wktad - staje się automatycznie partnerem dorostych. Może pertraktować z nimi niemal we wszystkich sprawach, zaktadajac petna wzajemność i jawność. Jest to prawdziwa szkoła społecznego wspótżycia $i$ współdziałania ${ }^{15}$.

Opisywany model ma wiele cech kultury kofiguratywnej Margaret Mead ${ }^{16}$. To starsi odgrywają główną rolę, wyznaczają formy i granice kształtowania zachowań młodych ale oni wzorują swoje postępowanie na zachowaniach rówieśników. Każda jednostka kształtuje własny styl życia, staje się wzorem dla swojego pokolenia. Międzypokoleniowe zmiany nie są istotne, ponieważ dotyczą sfer, którymi nie zajmuje się starsze pokolenie. Dziadkowie wywierają ograniczony wpływ na wychowanie wnuków i nie oczekuje się od nich wzoru postępowania. To młodzi często stają się autorytetami nowego stylu życia, a rodzice tracą możliwość kontroli i osądu.

\footnotetext{
${ }^{14}$ M. Mead, Kultura i tożsamość. Studium dystansu międzypokoleniowego, Warszawa 2000.

${ }^{15}$ K. Jankowski, Nie tylko dla rodziców, Warszawa 1980, s. 106-107.

${ }^{16}$ M. Mead, Kultura i tożsamość...
} 


\section{Autonomiczny model relacji dziecko-dorosły, określany mianem samowychowania albo autosocjalizacji dziecka}

W modelu trzecim dzieciństwo traktowane jest jako indywidualna i autonomiczna faza rozwoju człowieka. Dzieci nie są biernymi obiektami wychowawczymi i odbiorcami informacji społecznych. Stają się autorytetami we własnej sprawie, aktywnymi podmiotami i twórcami swojego środowiska. Mogą budować swoją własną społeczność jako alternatywę dla społeczeństwa dorosłych. Zwraca się uwagę, że wychowanie jest szkodliwe, blokuje dojrzałość dzieci oraz wpływa negatywnie na ich relacje z dorosłymi.

W autosocjalizacji dziecka wyróżnić można dwie perspektywy: pierwszą opartą o kompetencje oraz drugą, której podstawą jest tworzenie autonomicznych społeczności/republik. Koncepcja wskazująca na kompetencje dzieci pojawiła się w naukach humanistycznych w latach siedemdziesiątych XX wieku. U jej podstaw leży przekonanie, że dzieci mogą przekazywać informacje zwrotne dorosłym umożliwiając im $\mathrm{w}$ ten sposób odzyskanie utraconych kompetencji lub wyzbycie się nieefektywnych lub nieakceptowanych wzorów zachowania. Warunkiem powstania nowego typu relacji jest dialog między dziećmi i dorosłymi oraz otwartość i szacunek dla tego co ich różni. Zakres kompetencji dzieci wyraża się w tym, że od urodzenia są istotami społecznymi, potrafią wyznaczać treść i granice swojej integralności oraz kompetentnie współpracują, jeśli ze strony rodziców spotkają się z podobną formą postępowania. Przekazują dorosłym werbalne i niewerbalne informacje zwrotne, które stanowią cenne wskazówki na temat emocjonalnych i egzystencjalnych problemów rodziców.

Drugim wymiarem ukazującym autosocjalizację dzieci jest tworzenie przez nie społeczności opartych o autonomiczny system wychowawczy, odizolowany od dorosłych. Młodzi ludzie oddzielają się od starszych, ale korzystają z ich wiedzy i doświadczenia. Wspólnoty i republiki dziecięce bazują na tym, że dziecko żyje doświadczając, ucząc się i próbując, a to czego nie potrafi jest dla niego szansą by nauczyć się czegoś nowego. Wychowanie to droga od naturalnego do refleksyjnego dysydenctwa, które dzieci same wola wypróbowywać $i$ powinny sobie same zorganizowac ${ }^{17}$. Prekursorem tak rozumianego wychowania był ksiądz Edward Joseph Flanagan, założyciel ośrodka-gospodarstwo przypominającego wieś, którego młodzi mieszkańcy samodzielnie wybrali autonomiczną radę. Wspólnota stała się wzorem dla hiszpańskich republik dziecięcych. Jedną z nich był światowej sławy cyrk założony przez księdza Jesusa Silva Mendeza. Po kilku latach mała republika przekształciła się w miasto dziecięce. Mieszkali w nim także dorośli, ale występowali tylko w roli nauczycieli, doradców i pracowników oraz nie mieli prawa głosu. Wszelkie

\footnotetext{
${ }^{17}$ B. Śliwerski, Pedagogika dziecka..., s. 110.
} 
decyzje podejmowały dzieci, które za zarobione samodzielnie pieniądze opłacały koszty swojego utrzymania oraz wyżywienia.

Autonomiczny model relacji dziecko-dorosły ma wiele cech kultury prefiguratywnej $^{18}$, w której szybkie zmiany cywilizacyjne, postęp techniczny doprowadziły do buntu i rozłamu międzypokoleniowego. Rozwój mediów uświadomił młodym ludziom, że są obywatelami świata i ponoszą za niego odpowiedzialność. Model pierwszy jest najczęściej spotykany w większości społeczeństw. Stanowi on przeciwieństwo modelu trzeciego, który występuje w nielicznych, eksperymentujących grupach społecznych. Natomiast model drugi będący syntezą pierwszego i trzeciego nie jest realizowany przez żadne społeczeństwo ${ }^{19}$.

\section{Wyniki badań własnych}

Zainteresowana tematem prowadzę badania dotyczące preferencji nauczycieli edukacji wczesnoszkolnej i wychowawców świetlic szkolnych zakresie modeli wychowania dziecka wg typologii Hansa Sanera. Badane zagadnienie realizuję $\mathrm{w}$ ramach szerszego projektu, którego celem jest poznanie opinii nauczycieli wczesnej edukacji na temat różnych kwestii społecznych.

W celu weryfikacji autorskiej Skali Preferencji Modelu Wychowania Dziecka według typologii Hansa Sanera, narzędzia skonstruowanego na potrzeby moich badań, w 2009 roku przeprowadziłam badania pilotażowe na wybranej grupie studentów Wydziału Pedagogiki i Psychologii. Wzięło w nich udział 141 osób, do dalszych analiz zakwalifikowałam 134 kwestionariusze Skali Preferencji Modelu Wychowania Dziecka.

Wśród badanych osób zdecydowaną większość stanowią kobiety (92\%), co wynika prawdopodobnie z kierunku studiów oraz feminizacji zawodu nauczycielskiego. W badanej próbie dominowali studenci pierwszego i trzeciego roku studiów dziennych (43\%), co trzecia osoba studiowała wieczorowo na czwartym roku, natomiast pozostali byli to studenci pierwszego roku studiów zaocznych drugiego stopnia. Większość badanych studentów (76\%) w przyszłości chciałaby pracować $\mathrm{w}$ zawodzie związanym $\mathrm{z}$ kierunkiem studiów, natomiast co dziesiąta badana osoba nie ma sprecyzowanych planów zawodowych. Niewielka część respondentów studiuje jednocześnie na drugim kierunku studiów. Studenci studiów dziennych częściej wybierają filologię polską oraz europeistykę natomiast studenci studiów wieczorowych teologię i ekonomię. Większość studentów studiów niestacjonarnych to osoby pracujące. Natomiast w dodatkową pracę, która najczęściej ma charakter dorywczy zaangażowany jest prawie co trzeci student studiów dziennych.

\footnotetext{
${ }^{18}$ M. Mead, Kultura i tożsamośćc...

${ }^{19}$ B. Śliwerski, Pedagogika pajdocentryzmu...
} 
Ponad połowa badanych studentów $(65,5 \%)$ wykazuje preferencje dla modelu równości (model II), tylko $9 \%$ akceptuje model samowychowania (model III) i $3 \%$ model I, czyli czym dziecko, ,jeszcze nie jest”. Co piąty badany deklaruje poparcie w takim samym stopniu dla modelu II i III. Pozostali studenci w takim samym stopniu akceptują kombinację modelu I i II oraz I i III lub wszystkich trzech możliwości (wykres 1).

Wykres 1. Wyniki badania pilotażowego Skalą Preferencji Modelu Wychowania Dziecka

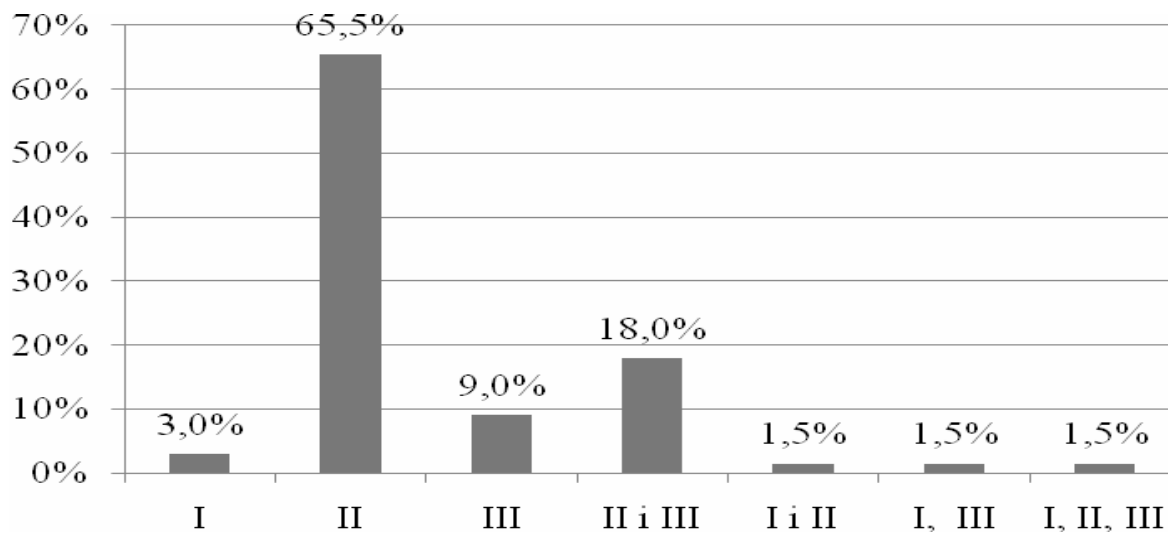

Źródto: badania własne

Badania pilotażowe wskazały, że twierdzenia zawarte w kwestionariuszu Skali Preferencji Modelu Wychowania Dziecka według typologii Hansa Sanera są dokładne i badani studenci nie mieli problemu z ich zrozumieniem. Zawarte w nim twierdzenia są adekwatne do tego czego ono dotyczy, są zrozumiałe dla badanych i jednoznaczne $\mathrm{w}$ swej treści. Badania pilotażowe przeprowadzone Skalą Preferencji Modelu Wychowania Dziecka potwierdziły trafność i rzetelnośćc ${ }^{20}$ tego narzędzia badawczego.

W związku z tym od marca 2010 roku prowadzę badania wśród białostockich nauczycieli edukacji zintegrowanej i wychowawców świetlic na temat ich preferencji w zakresie opisywanych Modeli Wychowania Dziecka. W chwili

${ }^{20}$ E. Babbie, Badania spoteczne w praktyce, Warszawa 2007; H. H. Krüger, Wprowadzenie $w$ teorie i metody badawcze nauk o wychowaniu, Gdańsk 2005; D. Silverman, Interpretacja danych jakościowych. Metody analizy rozmowy, tekstu i interakcji, Warszawa 2007; D. Silverman, Prowadzenie badań jakościowych, Warszawa 2008; D. Urbaniak-Zając, W poszukiwaniu kryteriów oceny badań jakościowych, [w:] Metodologia pedagogiki zorientowanej humanistycznie, pod red. D. Kubinowski, M. Nowak, Kraków 2006. 
obecnej w badaniach wzięło udział 40 nauczycieli zatrudnionych w 8 białostockich publicznych szkołach podstawowych, jednak do dalszych analiz zakwalifikowałam 39 kwestionariuszy Skali Preferencji Modelu Wychowania Dziecka. Wychowawcy świetlic, jak i nauczyciele młodszych klas szkoły podstawowej stanowili zbliżone liczebnie grupy (odpowiednio 19 i 20 osobowe).

Wykres 2. Wyniki badania przeprowadzonego wśród nauczycieli Skalą Preferencji Modelu Wychowania Dziecka

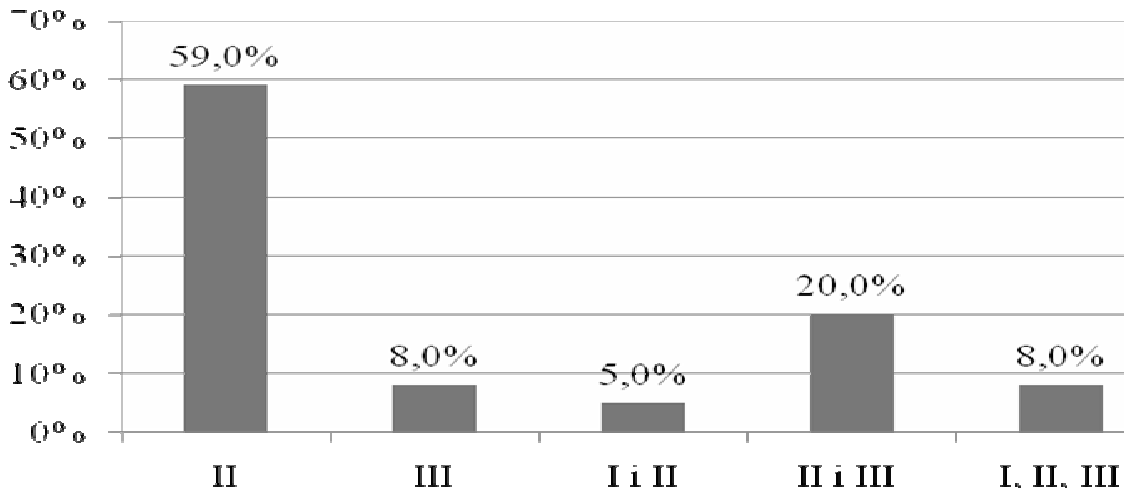

Źródto: badania własne

W badaniach uczestniczyli nauczyciele w rozległym przedziale wiekowym (od 25 do 54 lat), o zróżnicowanym stażu pracy (od 3 miesięcy do 29 lat), a w związku z tym z odmiennym doświadczeniem pedagogicznym. W badanej grupie ponad połowa osób (64\%) ukończyła studia stacjonarne, co trzeci studia niestacjonarne zaoczne, a tylko nieliczni (5\%) studia niestacjonarne wieczorowe. Nauczyciele dbają o swój rozwój zawodowy o czym może świadczyć fakt, że zdecydowana większość (69\%) posiada dyplom ukończenia studiów podyplomowych (najczęściej pedagogika wczesnoszkolna/elementarna lub opiekuńczowychowawcza), w tym niektórzy (25\%) dwóch specjalności. Wszystkie z nich są to kierunki pedagogiczne, jednak niektóre umożliwiają również pracę ze starszymi dziećmi i młodzieżą (doradztwo zawodowe, socjoterapia, resocjalizacja w środowisku otwartym). Ponad połowa badanych posiada stopień awansu nauczyciela dyplomowanego, co piąty jest nauczycielem mianowanym. Pozostali to nauczyciele najmłodsi, czyli kontraktowi (18\%), stażyści $(2,5 \%)$ jak również ci, którzy rozpoczęli pracę w bieżącym roku szkolnym (5\%) jednak ze względu na istniejące przepisy prawa oświatowego nie mogli rozpocząć procedury awansu zawodowego. 
Ponad połowa badanych nauczycieli (59\%) wykazuje preferencje dla modelu równości (model II), natomiast co piąta osoba deklaruje poparcie dla kombinacji modelu II i III. Pozostali badani w zbliżonym stopniu akceptują model III, czyli samowychowania (8\%), kombinację wszystkich trzech modeli (8\%) lub połączenie modelu I i II (5\%). Żadna z osób biorących udział w badaniu nie akceptuje modelu I, czyli modelu wychowania bazującego na tym, czym dziecko ,jeszcze nie jest” (wykres 2). Większość nauczycieli (92\%) wykazuje zdecydowane odrzucenie lub niskie preferencje dla tego modelu. Co czwarty nauczyciel nie akceptuje modelu samowychowania, natomiast w przypadku modelu równości co piąta osoba biorąca udział w badaniach.

Rysunek 1. Charaterystyka nauczyciela preferujacego model równości

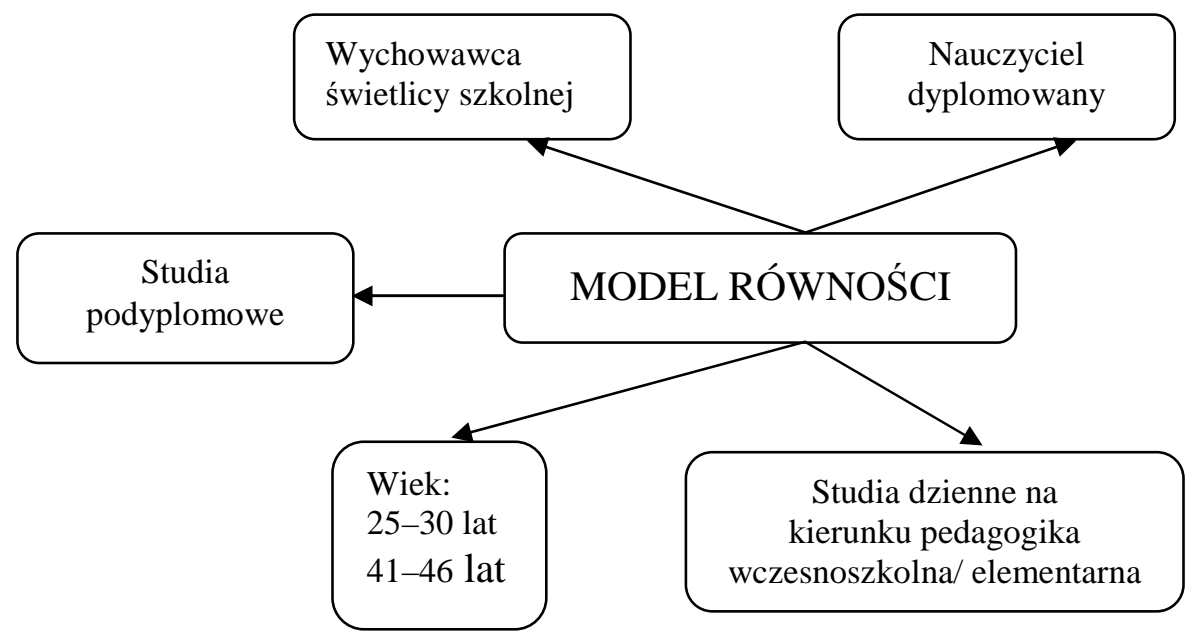

Źródto: badania własne

Wyniki przeprowadzonych przeze mnie badań wykazują wyraźne preferencje badanych nauczycieli dla modelu II, przy całkowitym braku akceptacji modelu pierwszego bazującego na tym „,czym dziecko jeszcze nie jest”. Prawdopodobnie wynika to $\mathrm{z}$ faktu licznych zmian społecznych, politycznych i gospodarczych oraz ich wpływu na zmianę podejścia do procesu wychowania dzieci. Badania zostały przeprowadzone wśród nauczycieli edukacji wczesnoszkolnej i wychowawców świetlic, a więc grupy osób, które przez wiele lat w trakcie studiów zdobywały wiedzę na temat wychowania najmłodszego pokolenia oraz systematycznie uzupełniają ją na licznych kursach i warsztatach, a także weryfikują w codziennej praktyce pedagogicznej. W związku z tym preferowane przez nauczycieli Modele Wychowania Dziecka mogą być odmienne od tych, które akceptują rodzice i opiekunowie. 


\section{Zakończenie}

Nauczyciele, rodzice, wychowawcy systematycznie podejmują się refleksji na temat wychowania, jego celów i skuteczności. Starają się stwarzać dzieciom optymalne warunki rozwoju, przekazywania wartości, norm, zasad obowiązujących w życiu społecznym. Jest to szczególnie trudne, a zarazem bardzo ważne w świecie globalizacji, licznych przemian społecznych, ekonomicznych, technicznych, kulturowych i politycznych, które wpływają na kształt współczesnej szkoły i funkcje rodziny. Podczas pracy nad tekstem pojawiły się nowe wątki, które z mojego punktu widzenia warte są rozpoznania, jak na przykład preferencje rodziców/opiekunów w zakresie Modeli Wychowania Dziecka wg typologii Hansa Sanera oraz ich przejawy w codziennym funkcjonowaniu rodziny.

MARTA WYSZYŃSKA

\section{Models of child's upbringing in contemporary world - report from the research}

During mutual interactions, adults have specific images of children, they have different expectations towards children and influence them in an active way. According to Swiss educator Hans Saner, there are different types of relations between educators and children: based on subordination, equivalence and relative independence. On the basis of these relations, Hans Saner distinguishes three models of child's upbringing in contemporary world: the model relying on something that a child 'has not been yet', the model of equivalence in relations between a child and an adult and the model of child's self-upbringing. In the article I present the results of my own research about preferences of the teachers from early school education and from common rooms in the field of child's upbringing models according to Hans Saner's typology. 